\title{
THE EFFECT OF SUKUK AND INFLATION ON THE PROFITABILITY OF ISLAMIC BANK IN INDONESIA
}

\author{
Mohammad Yusron Sholikhin ${ }^{1 *}$, Rachmania Nurul Fitri Amijaya ${ }^{2}$, Sri Herianingrum ${ }^{3}$ \\ *Corresponding Author \\ ${ }^{1,2,3}$ Faculty of Economics and Business, Universitas Airlangga, Surabaya, Indonesia \\ Mohammad.yusron.olikhin@pasca.unair.ac.id
}

\begin{abstract}
The purpose of this research is to determine the long-term and short-term effects of Sukuk and inflation on the profitability of Sharia banks in Indonesia. This study uses a quantitative method with a vector error correction model. The data used was monthly data Sukuk, inflation and profitability of Islamic banks in the years 2011 to 2018. The results of this research are in the long term Sukuk variables have a significant influence on ROA. The results obtained from the t-statistic values of variables Sukuk amounting -6.56088. The value is greater than $t$ table, Effect of Sukuk itself fairly small to ROA. While the variable inflation in the long term does not affect ROA, because the t-statistic value variable inflation was at -1.05310 . Then in the short term, Sukuk and inflation do not significantly influence ROA. This study is the first study that examines the influence of Sukuk and inflation on the profitability of Islamic banks using a vector error correction model.
\end{abstract}

Keywords: Sukuk, inflation, profitability, Islamic bank

Received

Revised

February 15, 2020

March 23, 2020

Accepted

Published

March 27, 2020

March 31, 2020

\section{INTRODUCTION}

Indonesia's financial sector is one sector which has an important role in promoting the national economy and the local economy. An Islamic bank is one of the financial sectors that its development so fast. It can be proved by the many offices existing Islamic banks in Indonesia. There is approximately 2556 Islamic banking office in December 2018 by the Islamic banking statistics from the FSA. It has been nearly 30 years of Islamic banks stand and show the development of financial performance. There are several aspects in assessing the financial performance either by aspect earnings or profitability. A profitability measure used is the return on assets (ROA) (Sufian, 2010). In general, the profitability of the company is defined as income generated from income after deducting all expenses incurred during a particular period. It is one of the most important factors that indicate shareholder management success in delivering satisfaction and attraction for investors and for companies that (Alarussi \& Alhaderi, 2018). Profitability is generally influenced by the costeffectiveness of the bank, asset quality, capitalization rate. Non-financial activities also maybe Islamic banks get for more. The better performance of Islamic banks can also be seen as GDP and investment are high(Zarrouk, Jedidia, \& Moualhi, 2016).

Changes in the profitability of Sharia banking can also be influenced by macroeconomic conditions. Banking as a business entity is also not spared from the instability of macroeconomic conditions where it will impact the banking function as an intermediate institution. Like some of the previous studies conducted by(Kassim \& Majid, 2010) explaining that banking intermediation functions are still affected by the instability of macroeconomic conditions. One of the macroeconomic variables whose condition fluctuates is inflation. Bank Indonesia explained that in 2008, the world economy was faced with a new chapter of the collapse of global economic stability, with the widespread financial crisis 
expanding to various countries. The global financial crisis began to emerge in the mid-2007, which is when one of France's largest banks is announcing the freezing of some securities related to the U.S. high-risk housing credit (subprime mortgage). This freezing then began to spark turmoil in the financial markets and eventually propagated around the world. As seen in the previous section that this unstable economic condition can certainly impact the profitability of banking.

In promoting the national economy the government also has the policy to increase the financial resources of the country through Islamic bonds or Sukuk. Sukuk is the Arabic term used to bonds based on Islamic principles. In the fatwa number 32 / DSN-MUI / IX / 2002, the National Sharia Council of Indonesian Ulama Council defines Sukuk as long-term securities based on sharia principles issued by the issuer to the holders of Islamic bonds that require the issuer to pay income to the holders of Islamic bonds in the form of profit-sharing margin or fee, as well as repay the bond at maturity (Huda, 2012).

In the expansion of Indonesia data indicates that within a few years the development of Sukuk increased it can be proved by the data of OJK as follows:

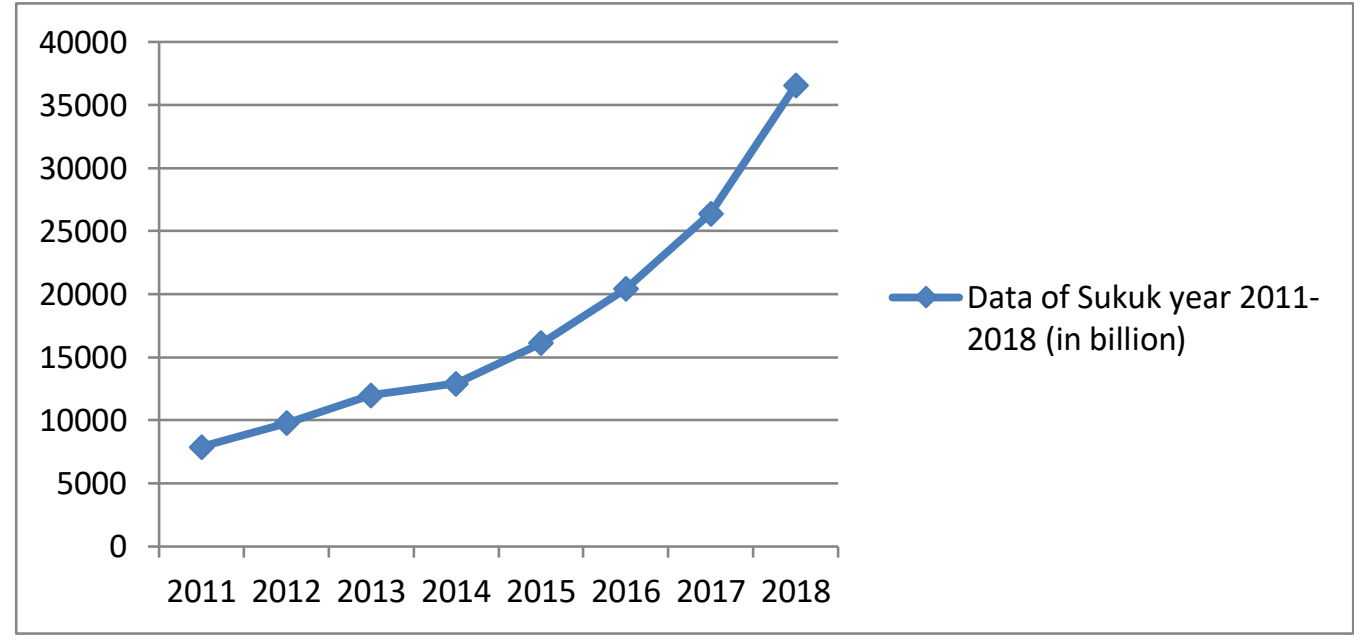

Figure 1. Data of Sukuk year 2011-2018

From the chart above Sukuk has increased continuously. It can be seen starting in 2011 until 2018 bonds continued to rise to reach Rp. 36545.4 billion. It is equal to the performance of Islamic banks have continued to rise. Then it can be seen that when the Sukuk in Indonesia continued to rise, the profitability of Islamic banks also increased. However, based on research from(Karim, Houcem, Akram, \& Moh'd, 2019)Sukuk has a negative effect on the performance/profitability of Islamic banks and conventional. This happens because the Sukuk is an investment product that competes directly with products of Islamic banks.

Along with the Sukuk or Islamic bank in Indonesia, not many studies that seek to influence their Sukuk on the performance of Islamic banking in Indonesia. It is interesting to be investigated by the relationship between Sukuk and Islamic banking in Indonesia. The data will be used is the monthly data profitability Islamic bank in Indonesia from 2011 until 2018 as the dependent variable.In addition, this paper used the Sukuk variable and the inflation that occurred at the time. The purpose of this paper is to find empirical evidence of Sukuk relationship and inflation on the profitability of Sharia banks in Indonesia. In particular, this 
research will also question the influence of Sukuk and inflation, in the long-term and shortterm. This is expected to provide information as a consideration to sharia banking in improving its performance amid the rise of Sukuk and inflation instability in Indonesia, particularly in increasing profitability Sharia banks. The next discussion in the second part of this paper will discuss previous study library studies. The third section describes the methodology used in this study. Then the next section explains the research findings and the last part of the researcher will conclude this paper by summarizing the research findings and providing suggestions for further research.

\section{LITERATURE REVIEW}

\section{Sukuk: Islamic Financial Instrument}

"Sukuk" stands for certificates and is the plural of sak, which means a certificate in Arabic (Iqbal \& Mirakhor, 2007). Sukuk are financial instruments issued by sovereign entities or corporations aiming at financing various projects and have become extremely popular in the past two decades (McMillen, 2007). Sukuk are an ingenious way of raising debt-like security with similarities to conventional bonds as far as cash flow and risk features are concerned. However, some researchers have argued that Sukuk mimic conventional debt/bonds with artificial differences (Usmani, 2007). Sukuk is one of the sharia bonds that enter the financial market. The relationship between the banking sector and the financial markets has been analyzed in some existing studies. Financial intermediation confirms the effect of competition between the banking sector and financial markets. If there is an increase in the outcome of interest in either party between Sukuk and banking will result in borrowers or lenders choose one of the types of banks and financial markets so it is called competing. Because it could make one of the parties decreased profitability. If the Sukuk increase then the banking profitability will decrease and vice versa. Then Sukuk is said to affect the profitability of banking.

\section{Inflation: Macro-Economic Instruments}

In general, inflation can be interpreted as an increase in the prices of goods and services of a general nature and is constantly. If the inflation is expected to rise, expenditure and borrowing by firms and households will reduce. As high inflation rates are generally associated with high-interest rates on loans, it can affect positively the bank profitability as it is evidenced by empirical studies devoted to Islamic banks (Izhar \& Asutay, 2007). As a result of the high inflation is the disruption of the function of money as a store of value, saving attitudes weaken, increasing the tendency for shopping, and direct investments in things that are non-productive (non-real) as accumulate wealth in foreign currency. According to(Harianingrum, Nafik H., Fauzi, Afifa, \& Laila, 2019) unemployment will reduce individual income so that purchasing power decreases, when purchasing power decreases, individuals have the possibility of not being able to meet their basic needs. Inflation alone is expected to have a positive relationship with profitability because if inflation increases and not anticipated financing will lead to greater cost, and it will result in the margin of the lower profitability of Islamic banks. 


\section{Factors Affecting the Profitability of Islamic Banking}

There are several aspects in assessing the financial performance either by aspect earnings or profitability. A profitability measure used is the return on assets (ROA) (Sufian, 2010). In general, the profitability of the company is defined as income generated from income after deducting all expenses incurred during a particular period. It is one of the most important factors that indicate shareholder management success in delivering satisfaction and attraction for investors and for companies whose sustainability (Alarussi \& Alhaderi, 2018). Profitability is generally influenced by the cost-effectiveness of the bank, asset quality, and capitalization rate. Non-financial activities also make it possible Islamic banks get for more. The better performance of Islamic banks can also be seen as GDP and investment are high (Zarrouk, Jedidia, \& Moualhi, 2016). (Zarrouk, Jedidia, \& Moualhi, 2016) also said that Sukuk could also affect the profitability of Islamic banks.

\section{Research Accomplished}

There are several studies discussing the influence of Sukuk and inflation on the profitability of Islamic banking. One is a study by(Karim, Houcem, Akram, \& Moh'd, 2019)which discusses the impact of Sukuk to the profitability of Islamic banks and conventional. The data used consists of 71 Islamic banks and conventional banks 146 which includes 13 countries during the period 2003-2004. Results from these studies negatively impact the profitability of the Sukuk. Then the Sukuk did not affect the performance of Islamic banks and conventional and also a negative effect on the profitability of Islamic banks are relatively low after the global financial crisis in 2008. Therefore this study concluded that Islamic banks were able to overcome the competition bonds after the crisis in 2008 .

In the opinion of (Hassan, Paltrinieri, Dreassi, Miani, \& Sclip, 2018)Sukuk and conventional bonds react to the lower conditional volatility against market volatility and a higher persistence, he also revealed that the return on the Sukuk is much less stable than conventional bonds in the United States and Europe. Furthermore, according to the time, he found a positive correlation between the return conditional Sukuk and bond markets are driven by changes in the macroeconomic and market conditions. During the recession, the dynamic correlation between Sukuk and bond markets is likely to increase. Further findings are a significant behavioral change in relation Sukuk and bonds, which are described by the liquidity of the market, the price of crude oil, the US credit information and the uncertainty of the stock market.

Then according to(Smaoui \& Nechi, 2017)which examines the impact of Sukuk to economic growth. Results from these studies are the Sukuk may have in promoting financial inclusion by eliminating the negative impact of the exclusion of religion itself, which stimulate investment and economic growth. The opinion of (Mahomed, Ramadilli, \& Ariff, 2018) examines the effect of Sukuk announcement during the crisis in Indonesia. Results from these studies are the event of the market reaction to corporate Sukuk issuances made by the company in Indonesia was not documented and these studies address the problem, 
especially during the period when the crisis of high-risk aversion and investors prefer liquidity.

Further study of(Khoutem, 2014)that describes the relationship between the Sukuk market in Islamic banks on economic growth. From these studies, the authors found that market intermediation Islam easily provide funds to finance economic development and solve the problem of poverty and unemployment. Islamic intermediation could be improved with the more important implication of the banks in the Sukuk market. It is possible to overcome the various problems associated with the mobilization of savings, bank liquidity management, risk-taking, and long-term investment.

\section{METHOD}

This study uses a quantitative approach, namely by documenting and analyzing the study data appropriately using statistical calculations. Malhotra in (Anshori \& Iswati, 2019) suggests that quantitative research aims to quantify the data and get the results that can be generalized by using statistical data analysis tools. (Sugiyono, 2012) explained that the quantitative method is based on the philosophy of positivism, is used to examine the population or a particular sample, using a data collection instrument of research, quantitative data analysis/statistics to test the hypothesis that has been set. The variables used in this research were data of Sukuk, inflation, and profitability (ROA).

Sukuk is long-term securities based on sharia principles issued by the issuer to the holders of Islamic bonds that require the issuer to pay income to the holders of Islamic bonds in the form of profit-sharing or fee margin, as well as repay the bonds at maturity from January 2011 until December 2018.

Inflation is a general rise in the prices of goods and services during a specific period. Inflation in Islam is not much different from the conventional is a symptom of the rising prices of goods that are general and ongoing. As a result of this price, increases could reduce people's purchasing power and lead to financing and the proposed loan to the Islamic banks will decrease.

Return on Assets (ROA) is a ratio used to measure a bank's ability to generate profits. The ratio is a pre-tax profit in the last 12 months compared to the average volume of business in the same period. ROA also explains asset turnover.

Monthly data used in this study from January 2011 to December 2018 (96 observations). The sample used was the entire Islamic banks registered in the FSA. The data used in this research is secondary data contained in monthly reports the FSA (financial services authority) and BI (Bank Indonesia) published through the website www.ojk.go.id and www.bi.go.id.

The analysis in this study used a vector auto regression (VAR) with the help of test equipment e-views 9. VAR is a method of alternative approaches to the double equation model with consideration to minimize the theoretical approach that aims to explain economic phenomena well (Azwar, 2016). All the variables in the VAR method called endogenous variables and there are no exogenous variables. When some variables are simultaneous, then these variables must be implemented, based on the same footing and there should be no difference between endogenous and exogenous variables, therefore, all variables are treated 
as endogenous variables(Gujarati D., 2004). In the VAR method, several tests must be conducted from the stationary test, determining the optimal lag, co integration test, the estimated VAR / VECM, impulse response function, and variance decomposition.

\section{RESULT}

The estimation models used in this study is the VAR model. But in practice, the model can be changed. Substitution model is based on the level of data stationer. If the data indicates stationary at the level of the level and the first difference then testing can be replaced with ARDL. However, when the data shows all stationary at the first difference then estimation model that can be used is unrestricted VAR (if no integration) and using the Error Correction Model (ECM) if there is co integration. The usage of ECM or Vector Error Correction Model (VECM) depends on the number of existing endogenous variables. However, if the data indicates difference stationary 1st and 2nd level difference is then used, Autoregressive models.

\section{Test of Stationary}

To view the data stationary then we need to test the unit root. Unit root test we will use in this test is the Augmented Dickey-Fuller test statistic. Her results are as follows:

Table 1. Test Stationary

\begin{tabular}{|c|c|c|c|}
\hline \multirow{2}{*}{ No. } & Research variable & \multicolumn{2}{|c|}{ Probability of Augmented Dickey-Fuller Test } \\
\cline { 3 - 4 } & & level & $1^{\text {st }}$ Different \\
\hline 1 & Sukuk & 0.9999 & 0000 \\
\hline 2 & Inflation (INF) & 0.3567 & 0000 \\
\hline 3 & Profitability (ROA) & 0.3905 & 0000 \\
\hline
\end{tabular}

Table 1 is the result of the stationary test on the 1st level and the level difference. The table above shows the level of data stationary Sukuk, inflation and ROA in Indonesia on 1st Different. Unit root test results of Augmented Dickey-Fuller indicates that the data Sukuk, inflation and ROA has a probability of 0.0000 which is less than the value of criticism by $5 \%$, so the null hypothesis that the data has not accepted the root unit. Therefore the data Sukuk, inflation and ROA can be said stationary at 1st level difference I. After the data stationary tests we will conduct further testing is determining the optimum lag and validity of the model.

\section{Determinant of Optimum and Validity Lag Model}

Selection of the optimal lag is a prerequisite in estimating equation VAR / VECM. In testing the unit root already made the determination optimal lag. However, the optimal lag test using the equation VAR feels more complete as all criteria are displayed in the test. Based on the optimal lag in table 2 of this study is the first since a lot of criteria that suggest that number. That is, in determining the optimal lag value markers star needed most. The following test results in an optimal lag in the study:

Table 2. Optimal Lag Test Results

\begin{tabular}{|c|c|c|c|c|c|c|}
\hline Lag & LogL & LR & FPE & AIC & SC & HQ \\
\hline 0 & -282.3938 & NA & 0.131677 & 6.486224 & 6.570678 & 6.520248 \\
\hline
\end{tabular}




\begin{tabular}{|c|c|c|c|c|c|c|}
\hline 1 & 79.56744 & 691.0170 & $4.32 \mathrm{e}-05 *$ & $-1.535624 *$ & $-1.197805 *$ & $-1.399525 *$ \\
\hline 2 & 83.87988 & 7.938800 & $4.81 \mathrm{e}-05$ & -1.429088 & -0.837905 & -1.190915 \\
\hline 3 & 91.41056 & 13.34985 & $4.99 \mathrm{e}-05$ & -1.395695 & -0.551148 & -1.055448 \\
\hline 4 & 94.82050 & 5.812402 & $5.68 \mathrm{e}-05$ & -1.268648 & -0.170737 & -0.826327 \\
\hline 5 & 106.4641 & $19.05321 *$ & $5.38 \mathrm{e}-05$ & -1.328730 & 0.022544 & -0.784336 \\
\hline 6 & 112.2150 & 9.018334 & $5.84 \mathrm{e}-05$ & -1.254885 & 0.349753 & -0.608417 \\
\hline 7 & 122.4001 & 15.27779 & $5.75 \mathrm{e}-05$ & -1.281821 & 0.576181 & -0.533279 \\
\hline 8 & 127.0284 & 6.626866 & $6.46 \mathrm{e}-05$ & -1.182464 & 0.928902 & -0.331848 \\
\hline
\end{tabular}

\section{Co integration Test}

In the analysis of Vector Auto Regression (VAR) cointegration test is required when the results of the test previously conducted stationary states stationary value at a level other than the data level. This means that when a stationary research data on different 1 st or 2 nd different it is necessary to test cointegration. Cointegration itself a long-term relationship between variables or original research data diverge in the short term will have a balance (equilibrium) in the long term. In the VAR analysis between variables that have enacted cointegration, VECM analysis. Cointegration determination can be seen by comparing the value of the Max-Eigen and trace its value. If the value of the Max-Eigen and trace its value is greater than the critical value of $1 \%$ and $5 \%$, then the data cointegrated.

Table 3. Unrestricted Co integration Rank Test (Trace)

\begin{tabular}{|c|c|c|c|c|}
\hline hypothesized & & Trace & $0: 05$ & \\
\hline No. of CE (s) & Eigenvalue & statistics & critical Value & Prob. $* *$ \\
\hline none $*$ & 0.395996 & 107.0556 & 42.91525 & 0.0000 \\
\hline At most 1 $*$ & 0.298021 & 60.67149 & 25.87211 & 0.0000 \\
\hline At most 2* & 0.263335 & 28.11719 & 12.51798 & 0.0001 \\
\hline \multicolumn{5}{|l}{} \\
\hline hypothesized & Max-Eigen & $0: 05$ & Prob. ** \\
\hline No. of CE (s) & Eigenvalue & statistics & critical Value & 0.0000 \\
\hline none * & 0.395996 & 46.38407 & 25.82321 & 0.0004 \\
\hline At most 1 * & 0.298021 & 32.55431 & 19.38704 & 0.0001 \\
\hline At most 2* & 0.263335 & 28.11719 & 12.51798 & \\
\hline
\end{tabular}

Based on the results of the co integration test, the value of Trace statistic is greater than the critical value of 5\% and $1 \%$. Besides, Max-Eigen value is also a larger critical value of $5 \%$, it can be concluded that the data are co integrated. This shows that there is a long-term relationship between inflation and unemployment rate variable is open. The co integrated data showing the right signals VECM method to use. Then we can determine the estimated VECM.

\section{Estimates VECM}

(Harapah, 2009)explained that the VECM is that these restricted VAR form. The restriction is given for the existence of the form data is not stationary at the degree level I (0), but co integrated. VECM then utilize the co integration restriction information into specifications. That's why VECM often referred to as VAR for non-stationary series which has a co integration relationship. It distinguishes between form VECM and VAR form is VECM requires that each variable in a state not stationary I (0) but has a co integration relationship. In this VECM estimates, will show the relationship between the variables of the other variables, both in the long term and short term. At the top table shows the relationship 
between variables in the long term, while the bottom shows the short-term relationships. Here are the estimated VECM in this study:

Table 4. VECM Estimation Results

\begin{tabular}{|c|c|c|c|}
\hline Co integrating Eq: & Coint Eq1 & & \\
\hline ROA (-1) & 1.000000 & & \\
\hline \multirow[t]{3}{*}{ Sukuk (-1) } & -5.515900 & & \\
\hline & $(0.84073)$ & & \\
\hline & {$[-6.56088]$} & & \\
\hline \multirow[t]{3}{*}{$\operatorname{INF}(-1)$} & -0.046303 & & \\
\hline & $(0.04397)$ & & \\
\hline & {$[-1.05310]$} & & \\
\hline \multirow[t]{3}{*}{ @ TREND (11M01) } & 0.104734 & & \\
\hline & $(0.01328)$ & & \\
\hline & {$[7.88680]$} & & \\
\hline $\mathrm{C}$ & 46.64580 & & \\
\hline Error Correction: & $\mathrm{D}(\mathrm{ROA})$ & D (Sukuk) & D (INF) \\
\hline \multirow[t]{3}{*}{ CointEq1 } & -0.076419 & 0.046176 & 0.455939 \\
\hline & $(0.09142)$ & $(0.01083)$ & $(0.19466)$ \\
\hline & {$[-0.83595]$} & {$[4.26566]$} & {$[2.34228]$} \\
\hline \multirow[t]{3}{*}{$\mathrm{D}(\mathrm{ROA}(-1))$} & -0.099982 & -0.038923 & -0.149824 \\
\hline & $(0.11899)$ & $(0.01409)$ & $(0.25336)$ \\
\hline & {$[-0.84028]$} & {$[-2.76244]$} & {$[-0.59134]$} \\
\hline \multirow[t]{3}{*}{$\mathrm{D}(\mathrm{ROA}(-2))$} & -0.237309 & -0.020721 & -0.211026 \\
\hline & $(0.11579)$ & $(0.01371)$ & $(0.24656)$ \\
\hline & {$[-2.04945]$} & {$[-1.51120]$} & {$[-0.85588]$} \\
\hline \multirow[t]{3}{*}{ D (Sukuk (-1)) } & -0.946421 & 0.085928 & -0.437893 \\
\hline & $(0.83981)$ & $(0.09945)$ & $(1.78825)$ \\
\hline & {$[-1.12695]$} & {$[0.86405]$} & {$[-0.24487]$} \\
\hline \multirow[t]{3}{*}{ D (Sukuk (-2)) } & 0.466797 & -0.064516 & 1.976213 \\
\hline & $(0.84882)$ & $(0.10051)$ & $(1.80743)$ \\
\hline & {$[0.54994]$} & {$[-0.64186]$} & [1.09338] \\
\hline \multirow[t]{3}{*}{$\mathrm{D}(\mathrm{INF}(-1))$} & 0.010014 & 0.000419 & 0.248741 \\
\hline & $(0.04867)$ & $(0.00576)$ & $(0.10363)$ \\
\hline & {$[0.20575]$} & {$[0.07277]$} & [2.40019] \\
\hline \multirow[t]{3}{*}{$\mathrm{D}(\mathrm{INF}(-2))$} & -0.023054 & -0.001981 & -0.239754 \\
\hline & $(0.04855)$ & $(0.00575)$ & $(0.10337)$ \\
\hline & {$[-0.47487]$} & {$[-0.34452]$} & {$[-2.31928]$} \\
\hline \multirow[t]{3}{*}{$\mathrm{C}$} & -0.003038 & 0.015694 & -0.066264 \\
\hline & $(0.03513)$ & $(0.00416)$ & $(0.07480)$ \\
\hline & {$[-0.08649]$} & {$[3.77300]$} & {$[-0.88592]$} \\
\hline R-squared & 0.116645 & 0.199745 & 0.158807 \\
\hline Adj. R-squared & 0.043898 & 0.133842 & 0.089533 \\
\hline Sum sq. resids & 6.536378 & 0.091656 & 29.63671 \\
\hline SE equation & 0.277306 & 0.032838 & 0.590480 \\
\hline F-statistic & 1.603430 & 3.030879 & 2.292429 \\
\hline Log-likelihood & -8.493724 & 189.9261 & -78.78455 \\
\hline Akaike AIC & 0.354704 & -3.912389 & 1.866334 \\
\hline Schwarz SC & 0.572562 & -3.694531 & 2.084192 \\
\hline mean dependent & -0.007450 & 0.016586 & -0.037849 \\
\hline SD dependent & 0.283600 & 0.035284 & 0.618833 \\
\hline \multicolumn{2}{|c|}{ Determinant resid covariance (dof adj.) } & $2.73 \mathrm{E}-05$ & \\
\hline \multicolumn{2}{|c|}{ Determinant resid covariance } & $2.08 \mathrm{E}-05$ & \\
\hline \multicolumn{2}{|c|}{ Log-likelihood } & 105.3819 & \\
\hline \multicolumn{2}{|c|}{ Akaike information criterion } & -1.664126 & \\
\hline
\end{tabular}


To see if a variable bonds and inflation affect ROA and vice versa can be seen by comparing the value of the $\mathrm{t}$-statistic estimation results with $\mathrm{t}$-table value. If the value of $\mathrm{t}$ statistic greater than the t-table, it can be said that the variable bonds and inflation affect the ROA.

Table 4 is estimated VECM with variable bonds, inflation, and ROA at lag 1 . The table is divided into two parts, namely the top and bottom. The top of the table it can be concluded that the variable Sukuk significant negative effect on ROA in the long-term. It is marked with $\mathrm{t}$-statistic -6.56088 values greater than $\mathrm{t}$-table on the degree of significance $(\alpha)$ of $1 \%$. While, variable inflation not significantly influences ROA. It is marked with a tstatistic value -1.05310 less than t-table on the degree of significance $(\alpha)$ of $1 \%$.

In the table below we can see the relationship between bonds and inflation on the ROA. In ROA at 1 torpor, it has no significant effect on ROA. ROA at 1 torpor significant negative effect on the Sukuk.ROA at 1 torpor no significant effect on inflation. ROA at inaction two gives significant negative effects on ROA. ROA at inaction 2 gives $\mathrm{n}$ significant effect on Sukuk. ROA at inaction 2 give no significant effect on inflation. Sukuk on inaction 1 and 2 had no significant effect on ROA, bonds, and inflation. Then inflation inaction 1 and 2 did not significantly affect ROA and Sukuk. Meanwhile, inflation in the $1^{\text {st }}$ and $2^{\text {nd }}$ inaction give significant and negative effect on inflation.

\section{Impulse Response}

To determine the effect of the shock in the economy then used the impulse response function method. During the coefficient on the structural VECM equation above is difficult to interpret so many practitioners recommend using impulse response function. Impulse response function describes the level of shock variable rate of one over the other variables in a given period range. So it can be seen the length of the effect of the shock of a variable against another to effect disappear or return to equilibrium. This function will track the response of the dependent variable when there is a shock in the $\mathrm{u} 1$ and $\mathrm{u} 2$. 
Response of ROA to ROA

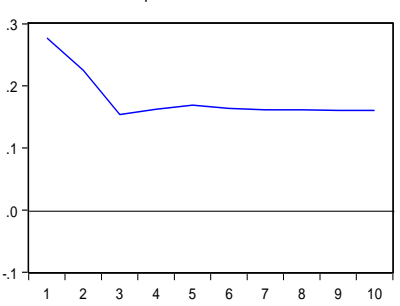

Response of SUKUK to ROA

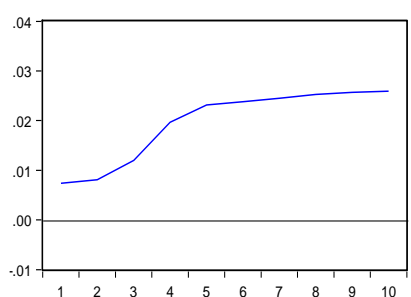

Response of INF to ROA

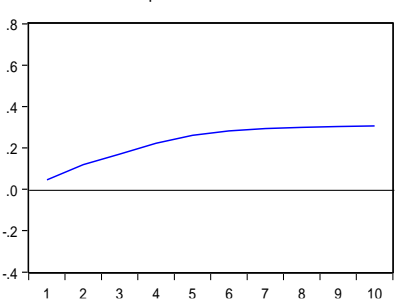

Figure 2. Impulse Response
Response to Cholesky One S.D. Innovations

Response of ROA to SUKUK

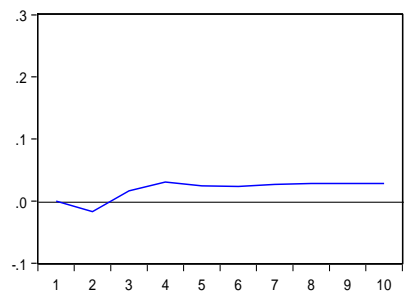

Response of SUKUK to SUKUK

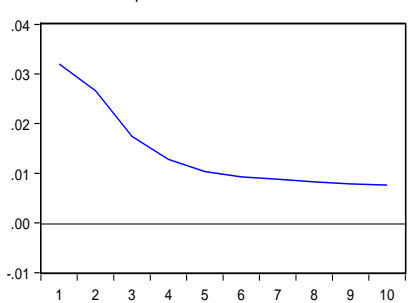

Response of INF to SUKUK

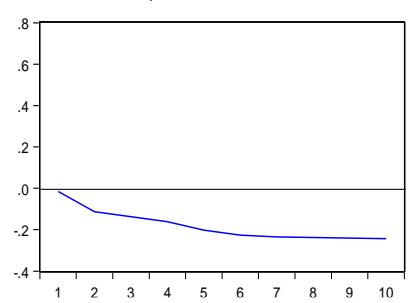

Response of ROA to INF

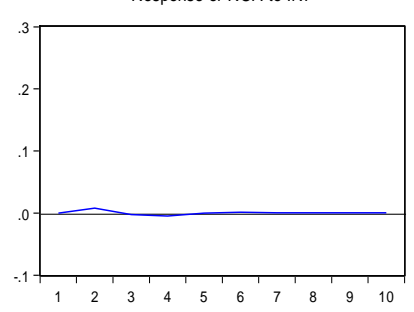

Response of SUKUK to INF

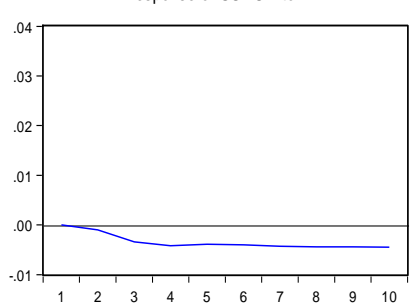

Response of INF to INF

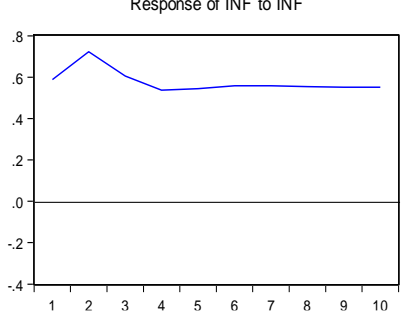

From the results above, it can be interpreted as follows:

a. In the upper left quadrant, indicating the ROA variable changes in response to their shock/change ROA at slowness. At the beginning of the period, their shock at first responded negatively ROA year to year 3 . Then move to the positive direction and start parallel with balance line up period 10 .

b. In the upper quadrant Sukuk amid their shock responded negatively responded by ROA up period 2. Next, move positively in period 3 and move stable until the period of 10 . This means that in the long term when there is a change could affect ROA Sukuk Islamic banking.

c. On the right upper quadrant of shock Inflation, their positive response to the move appropriate balance line up period means that even if there is inflation 10. ROA in Islamic banks tends to be stable.

d. In the middle of the left quadrant, a Sukuk for their shock response ROA. From these images, we can see that when there is a shock ROA in period 1 will respond positively to the period ROA 10. That change could affect the movement of the Sukuk.

e. In the mid quadrant of the central part, a response Sukuk for their shock. The response in period 1 to period tends to negative 10 .

f. In the middle right quadrant is a response to the Sukuk when the shock on inflation. Sukuk tend negative response from the first year and began to stable from period 4 to period 10. This means that when there is a change in inflation could affect negatively Sukuk. 
g. At the bottom left quadrant Inflation response occurs when the shock on ROA. In the first period to period 6 occurs positive and stabilizing effect until 10. That period could occur when the effect of a change in ROA.

h. At the bottom quadrant of the center, the inflation response to shocks that occur in Sukuk. The result is the shock in Sukuk in one responded negatively by inflation of up to 10 years.

i. At the bottom right quadrant, is the response of inflation to the inflation shock. The result in the early years when the shock on inflation, inflation has a positive effect and tends to be stable up to 10 periods.

\section{Variance Decomposition}

Variance decomposition will provide information on the proportion of the movement of the shock effect on a variable to another variable shock in the current period and future periods. Decomposition variance function on VAR and VECM is the same. Below is a table of variance decomposition:

Table 5. Variance Decomposition

\begin{tabular}{|c|c|c|c|c|}
\hline \multicolumn{5}{|c|}{ Variance Decomposition of ROA: } \\
\hline period & SE & ROA & Sukuk & INF \\
\hline 1 & 0.277306 & 100.0000 & 0.000000 & 0.000000 \\
\hline 2 & 0.357672 & 99.72454 & 0.225732 & 0.049728 \\
\hline 3 & 0.389625 & 99.59048 & 0.363258 & 0.046257 \\
\hline 4 & 0.423318 & 99.11199 & 0.835077 & 0.052933 \\
\hline 5 & 0.456509 & 98.95356 & 1.000917 & 0.045520 \\
\hline 6 & 0.485524 & 98.83707 & 1.122002 & 0.040927 \\
\hline 7 & 0.512388 & 98.67788 & 1.285305 & 0.036811 \\
\hline 8 & 0.537902 & 98.52679 & 1.439791 & 0.033417 \\
\hline 9 & 0.562075 & 98.39999 & 1.569345 & 0.030666 \\
\hline 10 & 0.585156 & 98.28884 & 1.682778 & 0.028383 \\
\hline \multicolumn{5}{|c|}{ Variance Decomposition of Sukuk: } \\
\hline period & SE & ROA & Sukuk & INF \\
\hline 1 & 0.032838 & 5.086018 & 94.91398 & 0.000000 \\
\hline 2 & 0.043050 & 6.489806 & 93.45498 & 0.055211 \\
\hline 3 & 0.048082 & 11.40633 & 88.03839 & 0.555285 \\
\hline 4 & 0.053679 & 22.60258 & 76.34367 & 1.053748 \\
\hline 5 & 0.059496 & 33.56690 & 65.14793 & 1.285172 \\
\hline 6 & 0.064871 & 41.68733 & 56.85246 & 1.460212 \\
\hline 7 & 0.070041 & 48.01934 & 50.35112 & 1.629542 \\
\hline 8 & 0.075055 & 53.17199 & 45.06182 & 1.766186 \\
\hline 9 & 0.079846 & 57.34808 & 40.78254 & 1.869387 \\
\hline 10 & 0.084418 & 60.74352 & 37.30533 & 1.951141 \\
\hline \multicolumn{5}{|c|}{ Variance Decomposition of INF: } \\
\hline period & SE & ROA & Sukuk & INF \\
\hline 1 & 0.590480 & 0.594452 & 0.063097 & 99.34245 \\
\hline 2 & 0.947372 & 1.806343 & 1.439017 & 96.75464 \\
\hline 3 & 1.145055 & 3.432129 & 2.430016 & 94.13786 \\
\hline 4 & 1.294373 & 5.638870 & 3.465945 & 90.89518 \\
\hline 5 & 1.442230 & 7.825396 & 4.755360 & 87.41924 \\
\hline 6 & 1.588254 & 9.617358 & 5.963024 & 84.41962 \\
\hline 7 & 1.724821 & 11.04703 & 6.902577 & 82.05039 \\
\hline 8 & 1.851324 & 12.19899 & 7.634582 & 80.16643 \\
\hline 9 & 1.970212 & 13.13854 & 8.234941 & 78.62652 \\
\hline
\end{tabular}




\begin{tabular}{|l|l|l|l|l|}
\hline 10 & 2.083180 & 13.91584 & 8.737304 & 77.34686 \\
\hline
\end{tabular}

In the first table, it shows decomposition variance of ROA. In the early period of both the variable bonds and inflation does not give any influence on ROA. So at the beginning of the period, ROA is affected by the variable itself. In the 2 nd period, both variables bonds and inflation started to give effect, albeit a very small contribution. Until the period of the 10 variables and the inflation, the effect is not too big to ROA, namely Sukuk amounting to $1.68 \%$, while inflation by $0.02 \%$.

In the second table, shows the variance of the variable decomposition Sukuk. At the beginning of the period just ROA which gives little influence on the Sukuk. Until the $10^{\text {th }}$ period of ROA and the inflation give impact of $60.74 \%$ (ROA) and 1.95\% (inflation).

In the third table, it shows the variance decomposition of variable inflation. At the beginning of the initial period of Sukuk and ROA variables affect only very little. Up to a period of 10 variables and ROA have influence Sukuk amounting to 8.73\% (Sukuk) and $13.91 \%$ (ROA).

\section{DISCUSSION}

The role of Sukuk on the profitability of Islamic banks can be seen from the results of data analysis explains that Sukuk significant negative effect on ROA. Those results proved the value of t-statistic Sukuk amounting -6.56088 larger than t-table on the degree of significance $(\alpha)$ of $1 \%$. The purpose of this is when Sukuk increases then ROA decreases. Then when Sukuk decreased the ROA will increase. Sukuk is one of the government's investment products to the public while the Islamic bank has its investment productsthat affect the profitability / ROA. This happens in the long term. The results of line with previous research on the(Karim, Houcem, Akram, \& Moh'd, 2019)who said the Sukuk negatively affect the performance/profitability of Islamic banks and conventional. This happens because the Sukuk is an investment product that competes directly with products of Islamic banks.

Later in the analysis of the results of inflation, it was found that inflation is no significant effect on the profitability of Islamic banks. This is evidenced by the analysis of research that shows the value of t-statistic -1.05310 less than t-table on the degree of significance $(\alpha)$ of $1 \%$. These results are consistent with previous studies conducted by (Zarrouk, Jedidia, \& Moualhi, 2016) that inflation does not affect the profitability of Islamic banks. Profitability is generally influenced by the cost-effectiveness of the bank, asset quality, and capitalization rate. Non-financial activities also make it possible Islamic banks get for more. The better performance of Islamic banks can also be seen as GDP and investment are high. (Zarrouk, Jedidia, \& Moualhi, 2016) also mentioned that the profitability of Islamic banks gets from Sukuk (Islamic bonds) and investment funds. It shows that bonds influence the profitability of Islamic banks.

\section{CONCLUSION}

The conclusion from the results and discussion of this research is in the long term Sukuk variable significant negative effect on ROA. The results obtained from the t-statistic values of variables Sukuk amounting -6.56088. The value is greater than t table. While the variable inflation does not significantly towards ROA.then the value of t-statistic variable 
inflation of -1.05310.Furthermore, in the short term Sukuk inaction 1 and 2 had no significant effect on ROA, bonds, and inflation. While the inflation in inaction 1 and 2 has no significant effect on ROA and Sukuk. Inflation in inaction 1 and 2 gives significant negative effect on inflation. So in the long term Sukuk significant give negative effect on ROA and inflation no significant effect on ROA. Then, in the short term Sukuk no significant effect on ROA and inflation no significant effect on ROA.

Based on the analysis of the results and the discussion in this study, associated with real conditions in the field, the policy implications that must be considered and observed are to be identified jointly, whether the customer, the regulator, Academics and observers of Sharia banks, regarding other factors affecting the profitability of sharia banks, both internal and external factors. Then the results of this research can be used as a comparison material for further research on sharia banking. Some recommendations from researchers are, using different variables, using the same case study for case studies in other countries, and further research using more recent analysis methods.

\section{REFERENCES}

Alarussi , A. S., \& Alhaderi, S. M. (2018). Factors Affecting Profitability in Malaysia. Journal of Economis Studies, 442-458.

Anshori, M., \& Iswati, S. (2019). Quantitative Research Methodology. Surabaya: Airlangga University Press.

Azwar. (2016). Allocative role of the goverment through goods / services and its effect on the economy Indonesia. study of financial economics , 149-167.

Gujarati D. (2004). Basic Econometrics, 4th Edition . New York : McGraw-Hill.

Harapah, P. (2009). Econometrics Module Tutorial . Yogyakarta: UGM.

Harianingrum, S., Nafik H., M., Fauzi, Q., Afifa, F. U., \& Laila, N. (2019). The effect of Goverment Expenditure on Islamic Human Development Index. Opcion, 685-703.

Hassan, M. K., Paltrinieri, A., Dreassi, A., Miani, S., \& Sclip, A. (2018). The determinants of co-movement dynamics between sukuk and conventional bonds. The Quarterly Review of Economics and Finance, 73-84.

Huda, N. (2012). Islamic Public Finance Approach Theoretical and Historical. Jakarta: KENCANA.

Iqbal, Z., \& Mirakhor, A. (2007). An Introduction to Islamic Finance: Theory and Practice. Hoboken, NJ: Wiley Finance Editions, John Wiley and Sons.

Izhar, H., \& Asutay, M. (2007). Estimating the profitability of islamic banking: evidence from Bank Muamalat Indonesia. Review of Islamic Economics, 17-29.

Karim, M., Houcem, S., Akram, T., \& Moh'd, A.-A. (2019). The Impact of Sukuk on the performace of conventional and Islamic banks. Pacific-Basin Finance Journal, 42-54.

Kassim, S., \& Majid, M. (2010). Impact of Financial Shocks on Islamic Banks: Malaysian Evidence during 1997 and 2007 Financial Crises. International Journal of Islamic and Middle Eastern Finance and Management, 291-305.

Khoutem, D. B. (2014). Islamic banks-Sukuk markets relationships and economic development: The case of the Tunisian post-revolution economy. Journal of Islamic Accounting and Business Research, 47-60.

Mahomed, Z., Ramadilli, S., \& Ariff, M. (2018). Sukuk announcement effects during financial crisis: the case for Indonesia. Journal of Islamic Accounting and Business Research, 567-686.

McMillen, M. (2007). Contractual enforceability issues: Sukuk and capital market development. Chicago Journal of International Law, 427-467. 
Smaoui, H., \& Nechi, S. (2017). Does sukuk market development spur economic growth? Research in International Business and Finance, 136-147.

Sufian, F. (2010). Does Foreign Presence Foster Islamic Banks' Performance? Empirical Evidence From Malaysia. Journal of Islamic Accounting and Business Research, $128-147$.

Sugiyono. (2012). Business Research Methods (quantitative, qualitative, and $R \& D$ approaches). Bandung: Alfabeta.

Usmani, M. (2007). Sukuk and their contemporary applications, Translated from the original Arabic by Sheikh Yusuf Tala DeLorenzo. Saudi Arabia: AAOIFI Shari'a Council meeting.

Zarrouk, H., Jedidia, K. B., \& Moualhi, M. (2016). Is Islamic bank profitability driven by same forces as conventional banks? International Journal of Islamic and Middle Eastern Finance and Management, 46-66. 